SURAKARTA ENGLISH AND LITERATURE JOURNAL

Publisher Language and Literature Faculty, University of Surakarta

ISSN Print: 2621-9077 ISSN Online: 2621-9085

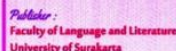

\title{
INDEPENDENT LEARNING FOR IMPROVING ENGLISH SKILLS OF STUDENTS IN ENGLISH LANGUAGE EDUCATION, PEKALONGAN UNIVERSITY
}

\author{
${ }^{1}$ Dwi Ario Fajar, ${ }^{2}$ Dwi Agustina
}

${ }^{1}$ Faculty of Teacher and Education, University of Pekalongan. dwiariof@gmail.com

${ }^{2}$ Faculty of Teacher and Education, University of Pekalongan. tina50@yahoo.co.id

\begin{abstract}
This research reports the findings of a narrative inquiry aiming at revealing the lecturers' perceptions about the meaning and importance of independent learning for improving students' mastery of English. This research involved nine lecturers of English Education program at the Faculty of Teachers' Training and Education, Pekalongan University. The lecturers were interviewed about their views of independent learning. The findings suggest that all of the respondents agreed on the importance of independent learning. However, in terms of the meaning of independent learning, the lecturers suggest a various definition of independent learning, signaling that their understanding on the concept of independent learning is not similar which may result in different practices of giving independent learning tasks to students.
\end{abstract}

Keywords: narrative inquiry, perception, independent learning.

\begin{abstract}
ABSTRAK
Penelitian ini melaporkan temuan penyelidikan naratif yang bertujuan mengungkapkan persepsi dosen tentang makna dan pentingnya pembelajaran mandiri untuk meningkatkan penguasaan siswa terhadap Bahasa Inggris. Penelitian ini melibatkan sembilan dosen jurusan Pendidikan Bahasa Inggris di Fakultas Keguruan dan Ilmu Pendidikan di Universitas Pekalongan. Para dosen diwawancarai tentang pandangan mereka mengenai pembelajaran mandiri. Temuan menunjukkan bahwa semua responden sepakat tentang pentingnya belajar mandiri.Namun, dalam hal makna belajar mandiri, dosen menyarankan berbagai definisi belajar mandiri, menandakan bahwa pemahaman mereka tentang konsep pembelajaran mandiri tidak serupa yang dapat mengakibatkan praktik yang berbeda dalam memberikan tugas belajar mandiri kepada siswa.
\end{abstract}

Kata kunci: narrative inquiry, persepsi, pembelajaran mandiri. 


\section{INTRODUCTION}

The concept of independent learning in English is called autonomous learning. It is a concept of learning that has been widely introduced not only in Western countries but also in Eastern countries. In this learning concept, students get greater responsibility in the learning process they do. Students are expected to be able to contribute to the learning process in their classrooms and outside the classroom after their classroom learning is over. The ideas and input from students regarding classroom learning are also highly expected, especially regarding the implementation of daily learning in the classroom. Because the students have a greater role in learning in their classrooms, learning activities are more student-centered rather than the teacher-centered. Teachers in this context only act as facilitators and motivators.

Egel (2009) states independent learning activities support the development of person into lifelong learners. If someone is given many opportunities to study independently, then he also has the opportunity to develop the skills needed by becoming lifelong learners. However, this opportunity certainly must be supported by the willingness of individuals to carry out these independent learning activities.

We realize it or not in this modern era, there has been a demand for individuals to become lifelong learners. Each learner is expected to be able to learn and develop themselves to follow the times and technological developments that continue rapidly. Jarvis (2007) and Weinstein et al. (2011) state that the ability to continue to learn and become lifelong learners will make individuals are not left behind by the times and will still be able to be part of the world community.

Along with the demands above, Indonesian education curriculum is also intended to be able to create students who are more independent and creative. The concept of learning is introduced in the classroom and also ultimately refers to the creation of independent learning activities. In general, the concept of independent learning has an appeal that is for several reasons.

The reasons which are most cited are the reasons presented by Crabbe (1993) that connect students' independence with their rights. According to Crabbe, every individual has learning needs, which of course must be fulfilled because the fulfillment of learning needs becomes an individual right. Thus they can learn things they like and want. In this context, individual rights can be fulfilled if the teacher is willing to involve students and give them freedom in choosing the material to be studied, strategies in learning, learning activities to be carried out in class, teaching materials, methods, evaluation of student learning outcomes, place and time right learning. However, giving this freedom must also consider aspects of the students' abilities and their learning needs.

Another reason that is often associated with the importance of independent learning activities is presented by Little (2009). Little underlines the superiority of independent learning activities in terms of effectiveness and efficiency. Little states that independent students can learn independently outside the classroom. Indeed, independent students will not be completely dependent on the teacher figure in their learning. So when they want to study they will not hesitate to do it even though they are not in school. Independent students will use the knowledge they get in class to help them learn new things they encounter outside the classroom. Thus independent children have the opportunity to improve their independence in

\section{Surakarta English and Literature Journal}


Vol.2, No.2 AUGUST 2019

learning. They explore more knowledge and at the same time, they develop into independent personality.

From the many reasons for using the concept of independent learning in education at present, it seems that the concept of independent learning is also understood differently. This is quite interesting because the concept of independent learning has been widely adopted but they are understood in various concepts. For example, the concept of independent learning is understood as a learning activity without assistance from a teacher (Little, 1991). However, this understanding and definition are refuted by Gremmo and Riley (1995) state that teachers still have a role when independent learning is carried out by students. According to them, teachers still play the role of facilitators, assistants, advisors, and tutors. Thus, even though children are introduced to the concept of independent learning. They do not necessarily escape the teacher's direction. The teacher helps them to be able to learn independently for example by giving tasks that require students to practice doing independently, either individually or in groups. The teacher can also assist according to the students' needs.

The dynamic curriculum change in Indonesia supports the concept of independent learning, especially in the 2013 curriculum. In this curriculum, learning is not teacher-centered. Facilitating is the teacher's duty in student learning. So that the impact that can be felt is that students are more active and independent in learning. Learning that focuses on students have been done in the previous curriculum, like homework. This means that independent learning has been applied but with different portions. But in this 2013 curriculum student learning independence is strongly supported.

Martin Lamb's research $(2004,2007$, and 2011) found that in one junior high school in one of a city in Sumatra there had done independent learning for students, especially learning English. The independent learning activities are carried out by watching English programs on television programs, listening to many English songs and practicing semi-self-taught English. The research shows that independent learning activities can be carried out since students are in junior high school. In other hands, independent learning can be done by junior high school students. It is possible if independent learning is applied at a higher level, for example at the senior high school level and higher education.

Learning is not only in the classroom, learning outside the classroom gives a lot of very significant contributions. This is because students spend a lot of time outside the classroom rather than in class. In theory, if students want to learn inside and outside the classroom, their abilities will be able to improve, what they learned in their class is learned or applied outside the classroom.

For example in the learning English, Dardjowidjojo (2000) analysis, the weakness of English language skills of high school graduates is caused by a lack of interaction in the classroom and low student independence. English is indeed a foreign language so the level of use of English is very weak in the application in their lives. Therefore, independent learning mustbe applied in their learning methods because it is very helpful in improving mastery of English, especially activities outside the classroom. Without independent practice, mastering children's English will be difficult to improve.

For students of English language education, mastery of English is a priority and skills must be mastered. English language skills are the most important thing for them such as reading skills, listening skills, writing skills, and speaking skills. Those in the English study

\section{Surakarta English and Literature Journal}


Vol.2, No.2 AUGUST 2019

program have four years of study. Four years is supposed to be a long time to learn languages. But what happened was that there were still many students in English language education study programs who faced difficulties in mastering these four skills. Independent learning is very appropriate if applied to students of English language education who need a lot of learning practices outside the classroom.

In higher education, independent learning activities strongly support students' mastery of lecture material. Because most learning methods on campus focus on student-centered learning, students can form study groups to support on their assignments. Or they can also independently carry out group learning activities even though they do not get special assignments from the Lecturer. For example, they can correct each other's writing, pronunciation and English skills. Such interactions are needed because they can improve their English skills. Today's interactions are also not limited to places. They can interact online. This online communication technology helps them to communicate with foreigners who speak English. Through the free chat application, they can communicate directly with native speakers. o do that, all of them needed interest from themselves. Students who have independent learning initiatives are students who have a high sense of responsibility and integrity.

Independent learning is a part of learning that has been carried out at Pekalongan University. It is just that there is no description of what and how important these independent learning activities are implemented in learning in English Language Education Study Programs. Therefore this research studies how the concept of independent learning is seen by lecturers inPekalongan University which needs to be implemented.

From the background described above, the problems discussed in the next discussion are formulated as follows: How is the perception of English Language Education Study Programs of Pekalongan University lecturers on the meaning of independent learning? What is the perception of English Language Education Study Programs UniversityPekalongan lecturers on the importance of independent learning activities for improving their students' mastery of English?

From the background described above, the problems discussed in the next discussion are formulated as follows: First, How do the lecturers in Study Program of English Language Education at PekalonganUniversity perceive the meaning of independent learning? Second, how do the lecturers in Study Program of English Language Education at Pekalongan University perceive the importance of independent learning activities for improving their students' mastery of English?

\section{METHODOLOGY}

This study is a qualitative research method specifically narrative inquiry. Narrative inquiry emphasizes the importance of using respondents' experience as the basis for data retrieval. In this case, the respondents' experience in implementing independent learning activities will be the basis for exploring their perceptions regarding the meaning and importance of independent learning.

Perception is a way of looking at a thing or problem. Perception is also equated with trust (Pajares, 1992). Everyone has a personal perspective that is often different from the

\section{Surakarta English and Literature Journal}


Vol.2, No.2 AUGUST 2019

perspective of others. Teacher's perception of trust is one of the research fields in theeducation that has been rarely studied (Borg \& Al-Busaidi, 2012). The teacher's perception of trust in a teaching method or technique will determine their teaching practice (Borg, 2001). Teachers can have good or poor perceptions, agree or disagree with matters related to educational practices, teaching methods, use of teaching materials, forwarding concepts of independent learning and so on.

In this study the writer did the interview by involving nine lecturers from English Language Education atPekalongan University. The interviews were in the form of unstructured interviews where the lecturers were asked about how they perceived the meaning and the importance of independent learning to facilitate the students' mastery of English. The interview lasted for around thirty minutes. The interview had been done in three months, September to December 2018.

Once the interviews have been done, the writer then transcribed the interviews. The transcribed were then coded to categorize the data into categories. Similar data with similar codes were grouped together into categories. The categories were then grouped into some sub themes which then became the main themes. The main themes were presented to describe the research findings based on the respondents' answers.

\section{FINDINGS AND DISCUSSION}

This section discusses the findings of the study in terms of the meaning of independent learning as perceived by the lecturers in English Language EducationatPekalongan University along with their perceptions about the importance of the independent learning for enhancing the students' mastery of English. The findings suggest all of the respondents considered that independent learning is important. However when the lecturers were asked to define independent learning, their answers varied. There were various meanings of independent learning described by the lecturers such as learning habits to master English, learning based on the students' needs and wants, utilization of self capacity and surrounding resources, and the learning efforts done without the presence of a teacher. This suggests that the lecturers had various perspectives regarding independent learning.

\section{The Meaning of Independent Learning in Lecturer Perception}

In the perceptions of lecturers, independent learning also has various meanings. First, independent learning was defined as learning habits to master English. More specifically the lecturers mentioned that independent learning is a kind of habituation in learning. This description of independent study was mainly for adult learners. In the lecturers' view, to master a foreign language, adult learners not only needed the learning but also the habituation. Habituation here referred to the learning of English in such a regular way and this was very important for mastering the language.Some of the meanings that appear in the findings of this study are:

a. Learning habits to master English

Independent learning is assessed as habituation

\section{Surakarta English and Literature Journal}




\section{Vol.2, No.2 AUGUST 2019}

"Independent learning for adult learners is very important. Moreover, language-related learning, which masters one language is needed not only learning and habituation but also be a part of independent learning"

b. Learning based on learners' wants and needs

Independent learning is assessed as a learning activity according to the wants and needs of the learners both in the classroom or outside the classroom. For activities that are in the classroom, independent learning is:

"Student active learning activities where students are involved in identifying what needs to be learned and control in the learning process."

Independent learning outside the classroom is:

"Independent learning is learning from the will of oneself because it is not from the encouragement of people so that the willingness to want and to know more and will be stronger to face the mental test and more patient, more mature in expressing their knowledge will also be more open to receiving input and more critical, and objective. "

c. Utilizing self-potential and resources around

Self-learning is also defined as the utilization of students' self-potential:

"Independent learning, in my opinion, is learning that utilizes all potential within oneself so that it can achieve learning goals"

Also, independent learning is defined as:

"Creative learning doesn't have to be companied with a certain topic. It is trying to dig up information from what's around him or her"

d. Individual learning activities can be carried out with lecturer or with no lecturer

For some lecturers, independent learning activities are carried out without dependence on the teacher or lecturer:

"Learning doesn't depend on the teacher so that they can understand better the best way they learn."

another answer also reinforces the opinion above:

"Independent learning is learning with enthusiasm, confidence, and perseverance with or without the help of others."

From the answers above, most lecturers consider that independent learning is done primarily by oneself without dependence on others.

One of the other respondents assessed that independent learning was done outside and in the classroom:

"Independent learning is a learning process carried out by individual learners in a wellstructured and unstructured way inside and outside the classroom. The learning process (not learning) whose output is a change in the behavior of the learner in all things. "

\section{Surakarta English and Literature Journal}


Vol.2, No.2 AUGUST 2019

In addition, independent learning was also defined as learning by utilizing the selfpotential and surrounding resources. One of the lecturers mentioned that independent learning referred to the learning done by utilizing all of the potentials within the learners so that they can achieve the learning objectives. The learning objectives in this case could be those related to the learning done at classroom or those related to the personal learning objectives. Besides, independent learning is also viewed as learning from the surrounding, finding information around us.

Independent learning is also defined as the learning done with or without the presence of a teacher. Some lecturers emphasized that in the independent learning students did not rely on the teachers. One of the lecturers stated without the dependence on the teachers or other people, the learners could find the best way to learn. This idea was supported by the statements of other respondents who mentioned that independent learning was done by full of motivation, diligence, and confidence. Another respondent also shared a quite similar idea that independent learning was done by individual either in a structured or in an unstructured way inside or outside of the classroom. This answer suggested that the independent learning was done individually.

Based on the answers above, it could be said that the lecturers shared a wide range of ideas related to the definition of independent learning. This may suggest that the lecturers' perceptions about the concept of independent learning were also different. The differences in understanding the meaning of the concept also signals that there were no uniformity in understanding the same concept of independent learning.

In terms of the importance of independent learning, the lecturers agreed that it is important. However the reasons presented to support their positive perception also varied. Among some of the reasons are discussed below.

Independent learning was perceived as important as it could help the learners to determine their learning styles. The students were also able to control and decide what materials to learn, and the best way to learn, for example though auditory, kinaesthetic, visual styles. This suggests that independent learning could provide more freedom for students in their learning.

Apart from the reason above, independent learning was also believed to be important as in learning English the learners need a lot of practices. One of the respondents mentioned that independent learning was very important as classroom practices were not sufficient. By practicing English independently in the environment, the learners could improve the four language skills.

Several lecturers also perceived that independent learning was very important for improving their students' skills in English. Therefore they often gave independent assignment to students like memorizing five vocabulary items every day and thus after they graduated, they had sufficient amount of vocabularyies. The lecturers thought that assigning individual tasks would affect students' learning positively.

The lecturers also opted independent learning due to its positive effects on students' language learning. Independent learning was chosen as a learning strategy which could be implemented with or without the guidance from the lecturers or friends. When the act of the learning was repeated every day, the students' English ability would gradually improve.

\section{Surakarta English and Literature Journal}


Vol.2, No.2 AUGUST 2019

Lastly, independent learning was also perceived as important as it could improve the learners' motivation and interests in learning. The lecturers believed that by doing independent learning, the students could be more motivated to learn English.

\section{The Importance of Independent Learning in Lecturer Perception}

In the lecturers' perception, independent learning was also considered important. Most of them thought that independent learning is very important for students. Second, independent learning was described as the learning based on the learners' need and wants. The lecturers perceived that independent learning was the learning proposed by the learners both inside and outside of the classrooms. In the classrooms, the learning could cover the students' learning activities where they were involved in identifying what they need to learn and they have the control over their learning. Outside the classroom, the independent learning could be in the form of independent study activities driven by the self curiosity about a particular topic. The topic might not be among those being learnt in the classroom. In learning the topic interested to the learners, the learners were also seen as being willing to accept the feedback and suggestion from others.

Following are the answers from the respondents:

a. It is very important that students can determine the material and individual learning style. One respondent answered:

"It is very important because students can determine the material to be studied and determine the right learning method for themselves (eg auditory, visual, kinesthetic, or mixed)"

b. It is very important because English requires a lot of practice. This can be seen from the answer of one respondent:

"Very important. English requires a lot of practice while the class practice is not enough. Mandiri by utilizing the surrounding environment can increase 4 abilities that must be mastered in English. "

c. It is very important to improve student language mastery. Some lecturers give the following opinion:

"Independent learning activities are very important for improving students' English skills. Therefore the teacher must provide assignments, for example, everyday students give five English words and their meanings so that students graduate their bachelor will have good vocabulary mastery. This will produce something positive.

Other lecturers have a similar opinion:

"Very important. Independent activities are a very good alternative for improving students' English skills. Whether it's with the guidance of lecturers on campus or with tutors, and learning independently, as well as learning independently with friends. When habituation is repeated every day, the student's English language skills will increase."

d. It is very important to increase student motivation and interest in learning. One respondent also considered the importance of independent learning

"Very important because with independent learning students have a high interest and motivation to learn English."

Surakarta English and Literature Journal 


\section{CONCLUSION}

The conclusion is that students generally have a positive perception of independent learning activities. Although students interpret independent learning with various interpretations, students have already practiced independent activities and felt many benefits of these activities. Students support when the lecturer gives the task in the form of independent learning activities. They also said that they would later provide independent learning activities to their students in the future when they became English teachers. For lecturers, independent learning activities are also considered important. However, lecturers also have different definitions of independent learning. Independent learning gives students the freedom to determine their learning style. So those students with their ways and learning styles, they can learn well in their classrooms. Independent learning in harmony with learning English. This is because English is a skill. Skill is not just a matter of knowledge but must be practiced in daily activities. Automatically, their language skills will increase. Self-learning is quite necessary for students because it will motivate their learning motivation.

Based on the discussion above, the lecturers in English Language Education Department of Pekalongan University had positive perception about independent learning. All of the lecturers agreed that independent learning should be implemented to enhance the students' mastery of English. Although the lecturers had various perceptions about the meaning of independent learning, the lecturers had acknowledged the benefits of independent study. This finding presents a positive image of the independent learning concept as perceived by the lecturers. This further suggests that the concept of independent learning is accepted and may continue to be implemented to support and enhance the mastery of English for English Language Education students.

\section{REFERENCES}

Agustina, D. (2017). A complex system of teachers' beliefs and practices in developing learner autonomy in Indonesian junior high school contexts: A mixed-methods study (Doctoral thesis, Victoria University of Wellington, New Zealand). Retrieved from http://researcharchive.vuw.ac.nz/handle/10063/6351

Agustina, D. Ario, D.F. (2018). Learner autonomy in as a challenge in English language education 4.0 in Indonesia.Proceedingsof the $2^{\text {nd }}$ English language and literature conference (ELLIC), 2 (155-159)

Borg, S., \&Alshumaimeri, Y. (2019). Language learner autonomy in a tertiary context:Teachers'beliefs and practices.Language Teaching Research, 23(1), 938.https://doi.org/10.1177/1362168817725759

Crabbe, D. (1993). Fostering autonomy from within the classroom: The teacher's responsibility.System, 21(4), 443-452.https://doi.org/10.1016/0346-251X(93)90056-M

Egel, İ. P. (2009). Learner autonomy in the language classroom: From teacher dependency to learner independency. Procedia - Social and Behavioral Sciences, 1(1), 2023-2026. https://doi.org/10.1016/j.sbspro.2009.01.355.

\section{Surakarta English and Literature Journal}


Vol.2, No.2 AUGUST 2019

Little, D. (2009).Learner autonomy, the European language portfolio and teacher development. In R. Pemberton, S. Toogood, \& A. Barfield (Eds.), Maintaining control: Autonomy and language learning (pp. 147-173). Hong Kong: Hong Kong University Press.

Jarvis, P. (2007). Globalisation, lifelong learning \& the learning society: Sociological perspectives. Abingdon, Oxon ; NY: Routledge.

Smith, R., Kuchah, K., Lamb, M. (2018) Learner autonomy in developing country. In Chik et al. (eds.), Autonomy in Language Learning and Teaching (pp. 7-27), https://doi.org/10.1057/978-1-137-52998-5_2

Weinstein, C. E., Acee, T. W., Jung, J., \&Dearman, J. K. (2011). Strategic and self-regulated learning for the 21st century: The merging of skill, will and self regulation. In B. Morrison (Ed.), Independent language learning: Building on experience, seeking new perspectives (pp. 41-54). Hong Kong: Hong Kong University Press. 